\section{Indicators for Assessing the Sustainability of Microalgae Production}

\author{
by Christine Rösch, ITAS, and Daniel Maga, \\ Fraunhofer UMSICHT
}

Sustainability studies on microalgae focus on high energy demand in the production process, which frequently leads to a negative energy balance. In doing so, other sustainability aspects, such as land use, carbon, nutrient and water demand, and socio-economic features such as the creation of new jobs and acceptance are neglected. By employing an integrative concept of sustainability, a systematic and holistic evaluation of sustainability is feasible and conflicts between sustainability targets can be discovered. In this article, an appropriate set of sustainability criteria and indicators for microalgae production is presented and preliminary clues are drawn regarding sustainability challenges and conflicts which should be taken into consideration in the further development of technology. ${ }^{1}$

\section{Introduction}

Great expectations are placed in microalgae that they can overcome the drawbacks that afflicted the production of first- and second-generation biofuels. This has led them to be called the source of third-generation biofuels. There are good reasons for this. Microalgae cultivation does not require arable land and thus does not trigger land use competition with food crops or deforestation for the creation of more farmland, making climate change worse. Microalgae can convert up to $5 \%$ of the sunlight energy to biomass (Schenk et al. 2008), which means that land use efficiency is higher than with traditional crops, whose photosynthesis efficiency only ranges between 0.5 and $1 \%$. However, today's technologies are far from reaching these theoretical yields under real conditions. Life cycle assessment studies have shown that microalgae production employing the current technologies is extremely energy intensive, making it difficult to achieve a positive energy balance (Lardon et al. 2009; Jorquera et al. 2010; Sander, Murthy 2010;
Stephenson et al. 2010; Collet et al. 2011). This is mainly due to the energy demand for mixing, harvesting, dewatering, extracting, and refining the final product. Conceptual and technological advances in reactor design and operation can result in a positive net energy and greenhouse gas balance (see Niels-Henrik Norsker and colleagues in this issue). Further environmental or social aspects are rarely part of technology development and are still considered as an "after-thought" once the technical and economic components of the technology and process design have been completed (Azapagic et al. 2006). A holistic and integrative sustainability approach is still required for the successful implementation of large-scale microalgae technology. This paper presents criteria and indicators for assessing the sustainability of microalgae products and provides preliminary clues to the sustainability challenges and conflicts along the process chain.

\section{Methodological Approach}

Translating the theoretical principles of sustainable development into a set of criteria and indicators for assessing algae-based products is by no means a trivial task because there is no standardized methodology for doing so. The primary challenges of grounding the theoretical framework of sustainability are

- identifying the relevant sustainability criteria and indicators,

- handling all principles of sustainability equally,

- applying an increased number of decision criteria, and

- comparison and trade-off of disparate criteria.

In this paper, the integrative concept of sustainable development (Kopfmüller et al. 2001) is taken as normative framework for identifying the sustainability criteria appropriate for microalgae production. This concept has not been specifically developed as an instrument for designing and evaluating technology but refers to the development of society as a whole in the global perspective (Grunwald, Rösch 2011). Nevertheless, it can be applied to develop criteria for assessing the sustainability of microalgae technologies. The concept is based on the three general principles of sustainable de- 
velopment being the conditions required for sustainability:

- securing human existence,

- maintaining society's productive potential, and

- preserving society's options for development and action.

The sustainability principles of the concept are listed in table 1 . They refer to aspects of human behavior where technology is just one aspect among others and cannot therefore all be used directly for assessing the sustainability of technologies. Causal and potential relationships have to be revealed to find out which principles are relevant to microalgae technology.

An analysis of coherence can be accomplished by reviewing libraries and web servers for relevant information in the literature, research articles, press releases, blogs, political acts and laws, certification standards, etc. Scientists involved in technology development and application should not be the only ones to conduct this task. On the contrary, opinions from society - i.e. the opinions of citizens, businessmen, representatives of ecological
Fig. 1: Selection of sustainability criteria and indicators for microalgae technology

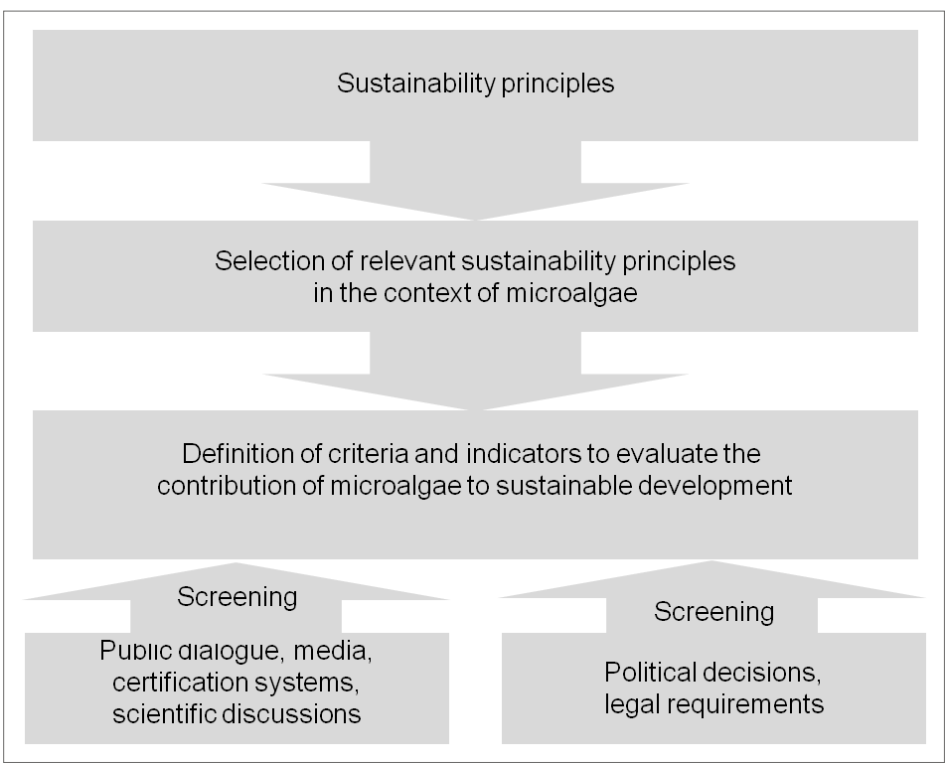

Source: Own compilation

Table 1: Principles of sustainable development

\begin{tabular}{ll}
\hline Main principles & Principles \\
\hline Securing human existence & Protection of human health \\
& Securing the satisfaction of basic needs \\
& Autonomous self-support \\
& Just distribution of chances for using natural resources \\
& Reduction of extreme income and wealth inequalities \\
& Sustainable use of renewable resources \\
Maintaining societal production potential & Sustainable use of non-renewable resources \\
& Sustainable use of the environment as a sink \\
& Avoiding technical risks with potentially catastrophic impacts \\
& Sustainable development of physical, human and knowledge capital \\
Preserving potential for societal development and & Equal access for all members of society to education and occupation \\
action & Participation in social decision-making processes \\
& Preservation of the cultural heritage and diversity \\
& Preservation of nature's cultural functions \\
Conservation of social resources (tolerance, solidarity, etc.)
\end{tabular}

Source: Kopfmüller et al. 2001, p. 172 
European Union, the Global Bioenergy Partnership (GBEP) or the Roundtable on Sustainable Biofuels (RSB) (Scarlat, Dallemand 2011). The methodological approach for selecting the relevant sustainability criteria and indicators is illustrated in figure 1.

The identification of criteria for ecological sustainability seems to be rather easy because a number of acknowledged criteria and indicators already exist, such as the energy, carbon, land and water footprints. The selection of one or a few indicators to reflect the criteria is, however, a tricky task. In social science, no consensus has yet emerged on the adequate criteria for social sustainability. The focus has been on personal assets such as consumption, income and employment as well as on institutional issues such as democracy, participation and gender equity. Due respect has to be paid to the importance attributed by various stakeholders to indicators of social sustainability and to the trade-off between social, environmental and economic indicators. The selected indicators have to be functional, robust and directionally safe. The derived indicators are different in quality and are specific to microalgae. They are rarely applicable to the macro-level of societies' social sustainability.

\section{Results}

It is not surprising that the relevance of each of the sustainability principles listed in table 1 is quite different for the assessment of microalgae technologies. The significance of some of these principles to microalgae technology is very strong while that of others is weak or there is no direct correlation at all. There is a strong correlation for the principles of securing human existence and maintaining the societal production potential.

Source: Own compilation
In contrast, the principles referring to societal development (see table 1) are less relevant because they refer primarily to a societal task and are related to societal organization, where technology only plays a minor role. In the following, we will briefly describe the sustainability principles that we consider relevant for assessing the sustainability of microalgae technology.

\subsection{Microalgae and Human Existence}

Microalgae technology can contribute to securing human existence because it can meet basic needs and contribute to human health and autonomous self-support (see table 2). Positive effects on human health can be achieved by substituting microalgae-based products for fossil fuel-based ones. No energy balance has yet been reached and the process could have a negative impact, e.g. by the demand for fossil fuels for microalgae production, as well as the use of toxic substances for reactor cleaning and the extraction of lipids or high-value substances from the cells (Halim et al. 2012). The risk to human health from microalgae is less than that from the land-based production of biomass because the closed production of the former allows for the controlled use, recycling and disposal of chemicals. Ecosystem services such as the recycling of carbon dioxide (Pires et al. 2012) and the nutrient removal from and phytoremediation of waste water provided

Table 2: Sustainability indicators for assessing microalgae technology - Part I

\begin{tabular}{|c|c|c|}
\hline Principle & Criterion & Indicator \\
\hline \multirow[t]{2}{*}{ Protection of human health } & Use of dangerous chemicals & $\begin{array}{l}\text { Type and amount of } \\
\text { chemicals used }\end{array}$ \\
\hline & Change in life expectancy & Disability adjusted life-years \\
\hline \multirow{4}{*}{$\begin{array}{l}\text { Securing the satisfaction of } \\
\text { basic needs }\end{array}$} & Supply of food supplement & Decrease in malnutrition \\
\hline & $\begin{array}{l}\text { Supply of feed for } \\
\text { aquaculture }\end{array}$ & $\begin{array}{l}\text { Substitution for aquafeed } \\
\text { from capture fisheries }\end{array}$ \\
\hline & $\begin{array}{l}\text { Supply of feed for terrestrial } \\
\text { animals }\end{array}$ & $\begin{array}{l}\text { Substitution for imported } \\
\text { feed protein }\end{array}$ \\
\hline & Supply of renewable energy & $\begin{array}{l}\text { Contribution to renewable } \\
\text { energy supply }\end{array}$ \\
\hline Autonomous self-support & Creation of new jobs & $\begin{array}{l}\text { Employment along the } \\
\text { supply chain }\end{array}$ \\
\hline
\end{tabular}


by microalgae can have a positive influence on human health (Rawat et al. 2011).

Microalgae can contribute to satisfying the need for food and energy in several ways. They are a commercial dietary supplement for humans in industrialized countries and a nutrient complement to combat the malnutrition in developing countries that a large part of the world population is still suffering from (see Christophe Hug et al. in this issue). They can also add to the food supply by providing feed supplements for aquaculture and feedstock (see Robin J. Shields et al. in this issue). The perspectives for using algal proteins in animal feed production are promising since protein is quite often the limiting ingredient in the large and growing market for animal feed. Microalgae can also help to meet the demand for renewable energy in manifold ways due to their ability to produce different energy carriers, such as biofuels, methane or hydrogen for transportation, assuming that a significant net energy yield can be achieved. The demand for food, feed and energy can be satisfied simultaneously in microalgae biorefineries (Mussgnug et al. 2010).

The criteria of socio-economic sustainability selected to illustrate autonomous self-support are employment and income (see table 2). In industrialized countries, employment depends mainly on the implementation of innovative high-level technologies. Many of the business models used in the algae industry, specifically those developed in Germany, are based on high technology and are supposed to create new "green collar" jobs providing employment for different specialists, such as scientists, engineers, and technicians, along the supply chain starting from research and development to manufacturing, operation, marketing, and sustainability monitoring. The algae industry can support local employment because the plants are designed for decentralized production, preferably based on the use of local nutrient streams. The premise behind the idea that the algae industry can create new jobs is the development of new markets for high-value products or a distinct reduction in production costs so that algal products can compete with and replace conventional products.

\subsection{Microalgae and the Societal Production Potential}

Microalgae can contribute to the sustainable use of renewable or non-renewable resources and of the environment as a sink. They thus have a strong relationship with the sustainability principles referring to the preservation of the societal production potential (see table 1). As already mentioned, microalgae can contribute to the supply of food, feed and energy, but techno-economic challenges need to be overcome to exploit this potential. Technological development in cultivation and downstream processing will lower the overall energy demand, yet achieving net energy production remains a challenge (Morweiser et al. 2010). Providing that this can be achieved, algal products can contribute to extending the availability of fossil fuel resources by replacing some uses of non-renewable resources and contributing to a reliable decentralized supply of energy. The amount that algal biofuels can contribute to the final energy consumption in the global transport sector is estimated to be significant (Harmelen, Oonk 2006; Skarka et al. 2011).

The resource phosphate is essential to all known forms of life. It is a limited resource that cannot be replaced. Around $70 \%$ of global phosphate production is currently produced from phosphate rock reserves, which will peak at the current rate of consumption in 30 to 50 years and will be depleted within 100 years (Copper et al. 2011). The future supply of phosphorus will be increasingly insecure and reliant on a handful of countries unless additional sources can be accessed or phosphorus recycling can be increased significantly. The main part of the global phosphate production is used in agricultural production, and microalgae also need large amounts of phosphate to achieve a high productivity. Nutritious waste streams can be used for algae cultivation, and part of the phosphates used for algae growth can be recycled subject to the processes applied downstream and the product range (Rösch et al. 2012). Even microalgae production systems with no additional demand for phosphates are possible if waste water is employed and the nutrients from the anaerobic digestion of the oil-free algal residues are recycled (Lundquist et al. 2010). 
The resource water is indispensable for microalgae cultivation. The quality and amount of water needed is determined by the water requirements of the specific algal species, e.g. their ability to grow in saline or waste water, and by the cultivation technology (open ponds or closed reactors). Since microalgae production systems are designed to approach profitability by achieving a high yield of lipids, generating high-value coproducts and being very productive, the use of waste water poses a great challenge that has hardly been investigated. The primary issue is that waste water carries algae that entail the development of mixed cultures consisting of different algal species. The use of salt water is limited to marine algae, and in open ponds fresh water is needed in the summer to prevent evaporation from creating excessive salt concentrations (Klöck 2010). For this reason, algae cultivation in open ponds can stress local water resources in warm climates and arid areas. The water demand in photobioreactors is generally lower than in open ponds. Cultivation water can be recycled, but currently no commercially viable concepts for large-scale water cleaning and recycling are available (Amer et al. 2011). In contrast to ponds, closed reactors need additional water for reactor cleaning and, depending on the technology used for temperature control in the summer, also for reactor cooling.

Arable land is an increasingly scarce resource facing a worldwide growing demand for food and biofuels and also land for settlement and traffic. As a result, agricultural production has been intensified, with negative consequences for sustainable land use. Cropland has been expanded at the cost of natural ecosystems, such as rainforests, and of the climate because these changes in land use result in large amounts of soil-bound carbon being released. Microalgae can contribute to sustainable land use as they can be cultivated on non-arable or marginal land without any changes in soil-related land use, and can achieve a high productivity and land use efficiency. Since there is a direct link between land use and biodiversity, microalgae can relieve the pressure on biodiversity by replacing biofuel production based on crops grown on arable or deforested land. Largescale microalgae cultivation could albeit disrupt the character of the landscape and change the nat- ural habitat of native wildlife (Klöck 2010). Another negative effect on local biodiversity could result from the demand for water for microalgae cultivation and from the release of emissions during the processing of microalgae (Goedkoop et al. 2009). By replacing the proportion of fish feed in aquaculture farms that rely on raw materials from capture fisheries (see Robin J. Shields et al. in this issue), microalgae cultivation can also contribute to the preservation of marine biodiversity.

The environment acts as a great sink for the redistribution, storage, processing, and absorption of human made wastes in the form of air emissions, soil and water discharges. The greatest challenge today with regard to ecological sink capacities is the increase in greenhouse gas emissions. One alternative is the creation of carbon sinks, e.g. by an increase in the amount of carbon fixed by photosynthesis. Ocean fertilization to enhance the growth of marine algae is one geoengineering approach to tackling climate change. Iron fertilization of otherwise nutrient-rich but iron-deficient blue ocean water can enhance algae growth. This can capture increased amounts of $\mathrm{CO}_{2}$, which is in turn sequestered as the algae sinks to the sea ground. Little is known about the potential impact on ocean ecosystems, making the idea quite controversial. In contrast, there is agreement on the use of flue gases from power and industrial plants as a source of carbon for microalgae cultivation. The $\mathrm{CO}_{2}$ uptake of microalgae plants is limited compared with the flue gas emissions from large power plants, and a positive greenhouse gas balance must be achieved before net savings can be claimed. Using current technologies, the European biofuel standardization requiring a greenhouse gas reduction of at least $35 \%$ today and $60 \%$ in 2018 cannot be realized, but the co-production of high-value algal products could reduce emissions by replacing conventional products that have even higher greenhouse gas emissions.

The environmental sink capacities can also be stressed by the fertilizer and pesticides released by cropping energy plants, leading to the contamination of groundwater and surface water. In contrast, fertilization in microalgae cultivation is performed in closed systems, and no nutrients are released into the environment. Moreover, algae can serve as a bioremediation agent for waste 
water cleaning. If microalgae or algal residues are used as feedstock at a biogas plant, the application of the fermentation residues can lead to nutrients leaching into surface and ground water. Since undesirable organisms, such as bacteria and wild algae, can grow in open ponds too, the application of pesticides over large areas could have an indirect effect on groundwater quality (Klöck 2010).

All technologies can result in unintended consequences and even risks to humans and nature. Some of them disappear, some develop into problems that can be handled, and a few have severe negative impacts, creating a lack of social acceptance. The acceptability of uncertainties and risks from technologies is related on the one hand to the benefits and on the other hand to the probability of an occurrence and the potential damage to humans and nature and the possibilities to limit the damage locally. The introduction of non-native algal species can pose a potential risk to the environment and marine biodiversity because the release of microalgae can have negative ecological flow-on effects such as altering food

Table 3: Sustainability indicators for assessing microalgae technology - Part II

\begin{tabular}{|c|c|c|}
\hline Principles & Criteria & Indicator \\
\hline \multirow{3}{*}{$\begin{array}{l}\text { Sustainable use of } \\
\text { renewable resources }\end{array}$} & Land use & Land footprint \\
\hline & Water deprivation & Water footprint \\
\hline & Impact on biodiversity & $\begin{array}{l}\text { Imperilment of valuable habits } \\
\text { for rare and protected plants and } \\
\text { ani-mals }\end{array}$ \\
\hline \multirow{2}{*}{$\begin{array}{l}\text { Sustainable use of } \\
\text { non-renewable re- } \\
\text { sources }\end{array}$} & Depletion of fossil energy & Primary energy savings \\
\hline & Depletion of minerals & Demand for phosphate \\
\hline \multirow{3}{*}{$\begin{array}{l}\text { Sustainable use of } \\
\text { the environment as } \\
\text { a sink }\end{array}$} & Climate change & Greenhouse gas savings \\
\hline & Aquatic eutrophication & $\begin{array}{l}\mathrm{NH} 3 \text { and } \mathrm{N} \% \text { emitted into the } \\
\text { air } \\
\mathrm{N} \text { and } \mathrm{P} \text { emitted into water }\end{array}$ \\
\hline & Acidification & $\mathrm{SO}_{2}$ equivalents \\
\hline $\begin{array}{l}\text { Avoiding technical } \\
\text { risks with potentially } \\
\text { severe impacts }\end{array}$ & Ecosystem changes & $\begin{array}{l}\text { Use of non-native algal species } \\
\text { Use of designer algae }\end{array}$ \\
\hline \multirow{3}{*}{$\begin{array}{l}\text { Sustainable develop- } \\
\text { ment of physical, hu- } \\
\text { man and knowledge } \\
\text { capital }\end{array}$} & $\begin{array}{l}\text { Development of innovative } \\
\text { process technology }\end{array}$ & $\begin{array}{l}\text { Opening of new markets } \\
\text { Export chances }\end{array}$ \\
\hline & $\begin{array}{l}\text { Employment and education of } \\
\text { scientists and qualified workers }\end{array}$ & $\begin{array}{l}\text { RTD expenditure, lectures and } \\
\text { professorships }\end{array}$ \\
\hline & $\begin{array}{l}\text { Generation of new knowledge } \\
\text { and innovation capacity }\end{array}$ & $\begin{array}{l}\text { Number of reviewed publica- } \\
\text { tions, patents and homepages }\end{array}$ \\
\hline
\end{tabular}

Source: Own compilation webs (Scholin et al. 2000), displacing native phytoplankton, causing local extinctions, and having serious societal effects (Backer et al. 2001). For the import and use of microalgae as live food for aquaculture and research only poorly regulated mechanisms exist (Campbell 2011). Genetic engineering of designer algae is not inherently associated with risks to ecosystems because these algae might not be robust and competitive enough to disseminate under natural conditions.

Algae technology is a nascent industry with limited physical, human and knowledge resources compared to long-standing fields of technology. In the last few years, more capital has been invested to push research and development and to generate knowledge and innovation capacities. Some academic institutes have set up dedicated algae research centres, and venture capital money has been raised for algae research in the USA. The big oil companies Chevron, BP and Exxon Mobil as well as many start-ups have made great investments in algal fuel research. The increase in research activities is mirrored by the number of conferences and workshops, research and review articles and conference papers, which has increased significantly in the last few years, e.g. from 400 (2004) to 893 (2010) (found in Scopus) and from 404 (2000) to 1,654 (2011; found in ScienceDirect). Since research into microalgae technology is in its early stages, it is difficult to assess the innovativeness and competitiveness of technologies developed in Germany as well as the chances to open new markets and benefit from export chances. The assessment of the 
impact on regional employment associated with the construction and operation of the microalgae production plants is even trickier.

\subsection{Microalgae and Societal Development}

Participation in social decision-making processes is important for the preservation of societal development and action potential, but this only affects the design of technologies which might be used for participation and is thus not applicable to microalgae technology. Since microalgae can contribute to satisfying essential human needs in the future, different members of society are interested in the development of microalgae technology. The participation of society in this development could be improved by involving people in decision-making processes on research programs and public expenditures for research, development and demonstration (RDD), but also in finding suitable locations for microalgae production plants.

Table 4: Sustainability indicators for assessing microalgae technology - Part III

\begin{tabular}{lll}
\hline Principles & Criteria & Indicator \\
\hline $\begin{array}{l}\text { Participation in } \\
\text { social decision- } \\
\text { making pro- } \\
\text { cesses }\end{array}$ & $\begin{array}{l}\text { Public participa- } \\
\text { tion in decisions } \\
\text { on public RDD } \\
\text { expenditures } \\
\text { and business site }\end{array}$ & $\begin{array}{l}\text { Stakeholder } \\
\text { workshops, web- } \\
\text { based question- } \\
\text { naires } \\
\text { focation search }\end{array}$ \\
$\begin{array}{l}\text { for algae plants } \\
\text { Preservation of } \\
\text { nature's cultural } \\
\text { functions }\end{array}$ & $\begin{array}{l}\text { scape changes } \\
\text { for microalgae } \\
\text { cultivation }\end{array}$ & $\begin{array}{l}\text { Location and } \\
\text { evant land }\end{array}$ \\
\hline
\end{tabular}

Source: Own compilation

The sustainability principles concerning the preservation of social resources and the cultural heritage and diversity (see table 1) are not affected by microalgae technology as long as their impact on the environment does not harm the cultural heritage, e.g. damage buildings by acidification. Likewise, the cultural and natural landscapes that are of particular characteristics and beauty are not endangered by microalgae production plants. Yet large-scale microalgae plants will change the landscape and can exert a local influence on nature as the object of sensual, contemplative, spiritual, religious and aesthetic experience. The cultural functions of landscapes could be affected even when marginal land is considered. No public discussion of suitable locations for microalgae plants has been started yet, but it is obvious that an acceptance analysis is needed at the beginning to identify possible barriers to acceptance and to use this information to determine locations of plants that can gain credence. The social acceptance of microalgae products is supposed to be quite high if it is possible to demonstrate their advantages over firstand second-generation biofuels and to achieve additional environmental benefits such as waste water remediation and $\mathrm{CO}_{2}$ capturing. No information is available on whether people are willing to promote and pay for algal products or if there are concerns about the incompatibilities of algal biofuels, their environmental and social impacts.

\section{Conclusion}

The integrative concept of sustainable development has been shown to provide an overall framework to carry out comprehensive and comparative assessments of sustainability. With regard to their applicability to microalgae technologies, 15 substantial principles of sustainable development have been identified as relevant and 22 sustainability criteria and indictors have been selected for assessing sustainability. Not surprisingly, the majority of the selected criteria refer to the satisfaction of basic human needs and maintenance of the societal production potential. Social aspects, such as participation in decision making, e.g. on the allocation of public funds for research, development and demonstration and on determining site locations, are not under discussion yet, but could become a topic in the future.

The enlargement of the criteria for assessing sustainability beyond the energy and greenhouse gas balance and the addition of further indicators resulting from comparative life cycle analysis would aggravate the problem of running into conflicts between sustainability criteria and the incommensurability of many criteria. For example, the use of waste water can reduce the demand for 
non-renewable nutrients for microalgae cultivation, but it has drawbacks with regard to the economic indicators and acceptance that might limit market access for high-value algal products. The integration of quantitative and qualitative results from different indicators is a prime challenge to being able to provide guidance for decision making about sustainability issues in microalgae technologies. Classical instruments such as life cycle assessment can help to aggregate results, but are by no means sufficient to handle the broad range of sustainability indicators even if they are further developed to meet social sustainability criteria such as consequential or social life cycle analysis. Since the impact of microalgae production strongly depends on the local conditions, especially the availability of sun, land, water, $\mathrm{CO}_{2}$ from flue gases, nutritious waste streams and of course infrastructure, regional assessments of the natural and human-made conditions of locations are required. This cannot be accomplished by life cycle analysis either.

A big advantage of applying the holistic sustainability concept to technology assessment is the ability to identify possible conflicts at an early stage. For example, the idea to use waste streams such as flue gases and waste water to produce highly specified and high-value coproducts is a contradiction. Qualitative procedures of deliberation for "soft" criteria of sustainability and for the consideration of conflicting objectives are necessary. The concept introduced in this paper does not solve these methodological issues, but provides a well-founded analytical framework for further improving the criteria for evaluating technology in a transparent and reliable manner.

\section{Note}

1) Dipl.-Landschaftsökologe Daniel Maga, B.Sc., works at the Fraunhofer Institute for Environmental, Safety and Energy Technology in Oberhausen, Germany.

\section{References}

Amer, L.; Adhikari, B.; Pellegrino, J., 2011: Technoeconomic Analysis of Five Microalgae-to-biofuels Processes of Varying Complexity. In: Bioresource Technology 102/20 (2011), pp. 9350-9359
Azapagic, A.; Millington, A.; Collett, A., 2006: A Methodology for Integrating Sustainability Considerations into Process Design. In: Chemical Engineering Research and Design 84/6 (2006), pp. 439-452

Backer, L.C.; Fleming, L.E.; Rowan, A.D. et al., 2001: Epidemiology and Public Health of Human Illness Associated with Harmful Marine Phytoplankton. In: WHO/UNESCO HAB Handbook

Campbell, M.L., 2011: Assessing Biosecurity Risk Associated with the Importation of Non-indigenous Microalgae. In: Environmental Research 111/7 (2011), pp. 989-998

Collet, P.; Hélias, A.; Lardon, L. et al., 2011: Lifecycle Assessment of Microalgae Culture Coupled to Biogas Production. In: Bioresource Technology 102/1 (2011), pp. 207-214

Cooper, J.; Lombardi, R.; Boardman, D. et al., 2011: The Future Distribution and Production of Global Phosphate Rock Reserves. In: Resources, Conservation and Recycling 57 (2011), pp. 78-86

DOE - Department of Energy, 2010: National Algal Biofuels Technology Roadmap. Office of Energy Efficiency and Renewable Energy, Biomass Program

Goedkoop, M.; Heijungs, R. et al., 2009: ReCiPe 2008: A Life Cycle Impact Assessment Method which Comprises Harmonised Category Indicators at the Midpoint and the Endpoint level. First edition. Report I: Characterisation. Amersfoort, Leiden, Nijmegen, Bilthoven, PRé Consultants, University of Leiden (CML), Radboud University Nijmegen (RUN), National Institute for Public Health and the Environment (RIVM)

Grunwald, A.; Rösch, Chr., 2011: Sustainability Assessment of Energy Technologies: Towards an Integrative Framework. In: Energy, Sustainability and Society 1/3 (2011); doi: 10.1186/2192-0567-1-3

Halim, R., Danquah, M.K.; Webley, P.A: 2012: Extraction of Oil from Microalgae for Biodiesel Production: A Review. In: Biotechnology Advances 30/3 (2012), pp. 709-732

Harmelen, T. Van; Oonk, H., 2006: Microalgae Biofixation Processes: Applications and Potential Contributions to Greenhouse Gas Mitigation Options. Prepared by TNO Built Environment and Geosciences for the International Network on Biofixation of $\mathrm{CO}_{2}$ and Greenhouse Gas Abatement with Microalgae

Jorquera, O.; Kiperstok, A.; Sales, E.A. et al., M.L., 2010: Comparative Energy Life-cycle Analyses of Microalgal Biomass Production in Open Ponds and Photobioreactors. In: Bioresource Technology 101 (2010), pp. 1406-1413 
Klöck, G., 2010: It's the Process, Stupid. Biofuels from Microalgae Are not yet Sustainable. In: Genetic Engineering \& Biotechnology News; http://www. genengnews.com/blog-biotech/it-s-the-process-stupid-biofuels-from-microalgae-are-not-yet-sustainable/587/ (download 13.7.12)

Kopfmüller, J.; Brandl, V. et al., 2001: Nachhaltige Entwicklung integrativ betrachtet: Konstitutive Elemente, Regeln, Indikatoren. Berlin

Lardon, L.; Hélias, A.; Sialve, B. et al., 2009: LifeCycle Assessment of Biodiesel Production from Microalgae. In: Environmental Science \& Technology 43/17 (2009), pp. 6475-6481

Lundquist, T.; Woertz, I. et al., 2010: A Realistic Technology and Engineering Assessment of Algae Biofuel Production. Berkeley, CA

Morweiser, M.; Kruse, O.; Hankammer, B. et al., 2010: Developments and Perspectives of Photobioreactors for Biofuel Production. In: Applied Microbiology and Biotechnology 87 (2010), pp.1291-1301

Muhs, J.; Viamajala, S. et al., 2009: Algae Biofuels \& Carbon recycling. Utah State University

Mussgnug, J.H.; Klassen, V.; Schlüter, A. et al., O. 2010: Microalgae as Substrates for Fermentative Biogas Production in a Combined Biorefinery Concept. In: Journal of Biotechnology 150/1 (2010), pp. 51-56

Pires, J.C.M.; Malvim-Ferraz, C.M.; Martins, F.G. et al., 2012: Carbon Dioxide Capture from Flue Gases Using Microalgae: Engineering Aspects and Biorefinery Concept. In: Renewable and Sustainable Energy Reviews 16/5 (2012), pp. 3043-3053

Rawat, I.; Ranjith, R.; Kumar, T. et al., 2011: Dual Role of Microalgae: Phycoremediation of Domestic Wastewater and Biomass Production for Sustainable Biofuels Production. In: Applied Energy 88/10 (2011), pp. 3411-3424

Rösch, Ch.; Skarka, J.; Wegerer, N., 2012: Materials Flow Modeling of Nutrient Recycling in Biodiesel Production from Microalgae. In: Bioresource technology 107 (2012), pp. 191-199

Sander, K.; Murthy, G.S., 2010: Life Cycle Analysis of Algae Biodiesel. In: International Journal of Life Cycle Assessment 15/7 (2010), pp. 704-714

Scarlat, N.; Dallemand, J.-F., 2011: Recent Developments of Biofuels/Bioenergy Sustainability Certification: A Global Overview. In: Energy Policy 39/3 (2011), pp. 1630-1646

Schenk, P.M; Thomas-Hall, S.R.; Stephens, E. et al., 2008: Second Generation Biofuels: High-efficiency
Microalgae for Biodiesel Production. In: BioEnergy Research 1 (2008), pp. 20-43

Scholin, C.; Gulland, F.; Doucette, G.J. et al., 2000: Mortality of Sea Lions Along the Central California Coast Linked to a Toxic Diatom Bloom. In: Nature 403 (2000), pp. 80-84

Skarka, J.; Rösch, C.; Posten, C., 2011: Microalgal Biomass for Biofuels in Europe - Production Potential with Regard to Land and $\mathrm{CO}_{2}$ Availability. 1st International Conference on Algal Biomass, Biofuels \& Bioproducts, St. Louis, Missouri, USA, July 17-20, 2011

Stephenson, A.L.; Kazamia, E.; Dennis, J.S. et al., 2010: Life-cycle Assessment of Potential Algal Biodiesel Production in the United Kingdom: A Comparison of Raceways and Air-lift Tubular Bioreactors. In: Energy Fuel 24 (2010), pp. 4062-4077

\section{Contact}

Dr. Christine Rösch

Karlsruhe Institute of Technology (KIT)

Institute for Technology Assessment and Systems

Analysis (ITAS)

Karlstraße 11, 76133 Karlsruhe

Phone: +49 (0) 721 / 608 - 22704

E-mail: christine.roesch@kit.edu

\section{$\langle\gg$}

